\title{
Chapter 27 \\ Diaspora Policies, Consular Services and Social Protection for UK Citizens Abroad
}

\author{
Erica Consterdine
}

\subsection{Introduction}

The objective of this chapter is to provide an overview of the diaspora policy infrastructure and key social protection policies implemented by the United Kingdom government for its nationals living abroad. In this chapter, I will show that UK policies for its citizens abroad are characterised by limited engagement but effective communication leading to a disengaged state that keeps the dialogue open.

The key policy that underpins UK diaspora relations is providing information and support through electronic platforms in addition to some dedicated consular efforts to encourage economic ventures such as supporting British businesses abroad. The UK has been characterised by Ragazzi (2014, p. 80) as a "expatriate state' which provides services to high-income category of "expats" employed for example in the transnational corporations of the sending states. Social protection policies on the other hand barely feature in the overall architecture of UK diaspora policy and are extremely limited.

Emigration policy is not effectively utilised as a form of soft power by the British state. The absence of state engagement stems from a lack of distinctive British identity, the heterogeneity of the British diaspora, and the profile of British emigrants having a typically 'international outlook' driven by positive pull factors with the assumption being that Britons living abroad do not want or need to engage with their homeland state. Furthermore, the Foreign and Commonwealth Office (FCO) which is the key department responsible for Britons abroad, has an organisational culture described 'as one of the last bastions of Westminster whiggism', with British diplomacy being 'renowned for being whiggish and reactive' (Hall 2013, p. 236). As a result, some have derided the FCO as failing 'to transform itself from a

\footnotetext{
E. Consterdine $(\bowtie)$

Department of Politics, Philosophy and Religion, Lancaster University, Lancaster, UK

e-mail: e.consterdine@ lancaster.ac.uk
} 
lynchpin of empire into a more flexible post-colonial institution' (Hall 2013, p. 237), and thus arguably diaspora policies suffer from policy inertia. Popular images of Britons abroad are 'often unfair and out-dated' but persist and 'perhaps contribute to a sense in parts of government that engagement with the diaspora is only about helping emigrants to keep out of trouble' (Finch et al. 2010, p. 14).

The UK is perhaps peculiar compared to other states in that immigration is highly politicised - arguably driving a public vote to leave the EU in the 2016 referendum (Dennison and Geddes 2018) - whilst at the same time the UK has almost no diaspora or emigrant policy to speak of and lacks any formal representative body or institution to represent Britons living abroad. There is no government minister or department with responsibility for emigrants, and no representative mechanism for Britons living abroad. Whilst there is little regional variation in the way of social protection policies for Britons residing abroad, the Scottish Government adopted a specific diaspora engagement plan to 'harness the power of Scotland's diaspora' (Scottish Government 2010). Nonetheless, the UK is peculiar in its absence of a formal diaspora policy, despite an estimated $5.6 \mathrm{~m}$ Britons living abroad (Finch et al. 2010). Furthermore, Brexit has served to underscore the lack of formal engagement between the British state and its citizens abroad, including concerns from the Britons living in the EU around pension transferability, and the contentious 15-year residency requirement which disenfranchised many Britons, highlighting what many decried as an unfair eligibility requirement.

The chapter begins by summarising the UK diaspora and its relation with the homeland. The chapter goes on to discuss the diaspora infrastructure for UK nationals residing abroad, key engagement policies of the UK state. The final section details the existing diaspora social protection policies including access to unemployment benefits, health care, pensions, family-related benefits and economic hardship.

\subsection{Diaspora Characteristics and Home Country Engagement Policies}

\subsubsection{The UK Diaspora and its Relation with the Homeland}

The UK diaspora is one the largest in the world, ranked eighth highest in absolute numbers (World Bank 2011), with the largest stock of citizens living aboard amongst high-income OECD countries (Murray et al. 2012, p. 19). This being said, estimating the stock of UK-born emigrants living abroad is challenging, with figures ranging from 4.5 to 5.6 million (Murray et al. 2012, p.18; World Bank 2011; Sriskandarajah and Drew 2006).

English-speaking nations have consistently been the top destinations for British emigrants, with Australia being the persistent top choice with an estimated $1,045,600$, followed by the USA $(798,000)$, Canada $(543,900)$, Spain $(280,500)$ and 
Ireland $(257,500)$. New Zealand, France and Germany are other important destinations (Murray et al. 2012). Australia is the top destination for younger age groups (aged 44 and under), whereas Spain and France are top destinations for older age groups (Murray et al. 2012, p. 17). Much of settlement emigration has taken place in countries of the Old Commonwealth as a result of colonial ties associated with the Commonwealth project and relatedly because these are English-speaking nations. Australia remains the top destination of choice in part because of family chain migration as a result of emigration in earlier decades and 'Empire continuing to exert its influence on settlement patterns long after it ceased to exist' (Hammerton 2017, p. 8). Thirty three per cent of all British born emigrants live in Australia or New Zealand (ONS 2018). In contrast the UK has a smaller proportion of citizens living in another EU country than any other EU state (ONS 2018). Nonetheless, as a result of more stringent entry requirements in Anglo sphere countries, and shifts to lifestyle migration, emigration to EU states has been on the rise since the 1980s with an estimated 784,900 British citizens living in the EU (excluding the UK and Ireland) in 2017 (ONS 2018).

British emigration has a long and fragmented history. In previous centuries Britons emigrated in large numbers to the colonies either as refugees or as forced economic migrants (Cohen 2008). Post-war Britain went through successive stages of austerity up to the early 1960s, and thus 'the emigration of the period was itself a one of austerity' (Hammerton 2017, p. 7). In the succeeding decades as UK became more prosperous, the patterns of migration shifted towards 'lifestyle migration' with Britons continuing to search for better employment but also preferred lifestyles such as warmer climate (Hammerton 2017, p. 7; Inter Nations 2017). In turn, emigration has been associated with 'dynamic, adventurous and often relatively prosperous individuals taking up exciting personal opportunities overseas' (Finch et al. 2010, p. 2). In contrast to other diasporas then post-war British emigration has been underpinned by positive pull factors. British emigrants tend to be 'progressive global Brits' who are self-mobilising. In turn the government's assumption is that Britons do not require or want engagement with the homeland and that engagement 'is only about helping emigrants to keep out of trouble' (Finch et al. 2010, p. 14). This reticence goes some way to explaining the lack of UK diaspora engagement policy.

Considering an estimated 6.6 million UK citizens live abroad (Finch et al. 2010, p. 13) the British diaspora is curiously absent from both scholarly and applied research. Academics and policy-makers have studied UK emigration far less than the immigration of people into the UK. Despite the fact that the majority of British emigrants do so for work or to accompany someone (Murray et al. 2012, p. 9-20) with the majority of British emigrants being of working age (aged 25-44 years) the majority of existing research focuses on British citizens retiring abroad (e.g. Howard 2008; King and Patterson 1998; King et al. 2000; O'Reilly 2000; Warnes et al. 1999). Among British citizens emigrating between 1991 and 2010, the largest group was consistently those with a previous occupation that was 'professional or managerial' (Murray et al. 2012, p. 13). Whilst there are large variations within countries, 'the British diaspora tends to be more highly educated and higher skilled 
than the general UK population' (Finch et al. 2010, p. 38). The evidence suggests that UK unemployment might be closely associated with emigration levels for British citizens (Murray et al. 2012, p. 35).

The lack of scholarly attention to the British diaspora is partly because diaspora studies generally focuses on groups that suffered from imperial oppression, in contrast to the British or even English diaspora, which are seen 'as progenitors of an empire against which outsiders were defined' (Bueltmann et al. 2012, p. 4). Yet perhaps the critical reason for the lack of research on the UK diaspora and more importantly the absence of a diaspora engagement policy is the UK being a multinational diaspora in the first instance, made up of English, Scottish, Welsh and Northern Irish, 'and in some cases these national identifications are stronger than a generic British one' (Finch et al. 2010, p. 13). For example, Scottish and Welsh emigrants 'are increasingly likely to identify with notions of Scottish or Welsh diaspora rather than British diaspora' (Finch et al. 2010, p. 25) and arguably Scottish identity is more defined than a wider British national identity, as reflected in the Scottish government's efforts to engage with its diaspora. British national identity is a relatively recent social construct, with a shifting debate in the last 20 or 30 years towards a renewed sense of Britishness to restore declining national prestige and pride (Finch et al. 2010, p. 75), a project perhaps never fulfilled and contentious in the current Brexit fuelled climate where the nation introspects about its national identity. At the same time, one of the most comprehensive studies on the British diaspora found that emigrants who had settled elsewhere long term maintained strong family, cultural and emotional links with the UK, few rejected the label of being British and many saw their Bristishness as positive in some way (Finch et al. 2010, p. 63, 43). This implies that despite the lack of a clear national identity there is a homeland maintenance which the government could engage with.

\subsubsection{Diaspora Infrastructure}

As outlined above, the British state has a limited diaspora engagement strategy, namely due to assumptions that Britons do not want or need to engage with their homeland. The infrastructure of engagement policies is therefore focused on providing comprehensive information whilst keeping the dialogue with its citizens open through social media channels. Whilst there is no specific service established the state maintains a commitment to keep the dialogue open and have people informed about their (limited or absence of) rights.

The key institution for diaspora engagement policy is the Foreign and Commonwealth Office (FCO). However, it is rare (indeed unheard of) for British officials to use the term diaspora or emigrants to describe UK citizens residing abroad (Hampshire 2013, p. 312). Conversely, the state generally refers to British emigrants as British Nationals Overseas or occasionally British expatriates.

The Foreign and Commonwealth Office's (FCO) key remit is to promote the UK's interest overseas including supporting UK citizens and businesses around the 
globe. They are the lead governmental institution by which the UK state engages with its national abroad. The FCO - created in 1968 when the Foreign Office and the Commonwealth Office merged - has three key responsibilities:

- Safeguarding the UK's national security by countering terrorism and weapons proliferation, and working to reduce conflict

- Building the UK's prosperity by increasing exports and investment, opening markets, ensuring access to resources, and promoting sustainable growth

- Supporting British nationals abroad around the world through modern and efficient consular services.

Within the FCO, the Consular Services are the key sub-ministry (although not officially a sub-ministry) by which the state assists Britons living abroad. A Directorate within the FCO provides the Consular Services; the Directorate consists of a network of $620+$ consular offices in embassies and consulates around the world. The Permanent Under-Secretary and Head of the Diplomatic Services role is to lead the Consular Services. There is no national-level public institution separate from ministries dedicated to addressing the needs of UK nationals residing abroad.

The FCO does not operate mobile consulates. In the absence of mobile consulates, the FCO relies on Honorary Consuls - of which there are just over 200 globally in 2018 - to be present in all major locations for British tourists and residents where no British diplomatic or consular mission exists. According to the FCO, Honorary Consuls provide an invaluable emergency response to crises or urgent consular cases, which are then reinforced and taken on by the consular teams in posts. The FCO states that Honorary Consuls provide a more accessible and responsive service in places where it could not justify a consular presence (Foreign Affairs Committee 2014, para 33). Honorary Consuls are volunteers (paid a stipend) who help assist British nationals where there is no full consular presence. Their duties may include crisis response, consular assistance, local authority liaison, or assisting official consular visits, but do not normally include routine consular services. The time devoted to consular matters varies widely between posts, but Honorary Consuls are expected to work on average no more than $4 \mathrm{~h}$ a week.

The regime relating to the functions of all consulates including Honorary Consuls are stipulated by the Consular Relations Act 1968, which transposed Article 5 of the Vienna Convention on Consular Relations (VCCR). Honorary Consuls work under the supervision of superintending posts and 'their work is carefully managed and monitored by trained Consular staff who assess whether the task is appropriate for delegation to an Honorary Consul or whether a full time member of staff ought to be deployed' (Foreign Affairs Committee 2014). For crisis response, the FCO established the Global Response Centre (GRC) that handles out-of-hours calls from members of the public who need urgent consular assistance.

The FCO Services, which is an executive agency of the FCO, provides protection to physical assets but this body provides no role or dedicated services to addressing the needs of nationals residing abroad. The British Council (BC) is an executive non-departmental body of the FCO that is the UK's international organisation for cultural relations and educational opportunities aiming to build lasting relationships 
between the UK and other countries. However, the British Council is no longer the prerogative of the state, and it is not within their remit to address the needs of British nationals residing abroad.

Aside from the FCO, a further relevant state ministry involved in a minor way in assisting some nationals residing abroad is the UK Visas and Immigration (UKVI) which is a division of the Home Office - responsible for running the UK visa service. In March 2014, the Home Office assumed full responsibility for passport applications, decisions and document issuance. In June 2014, there were delays in issuing passports. To help deal with problems issuing passports for UK citizens overseas, the FCO extended passports by 12 months and began to issue emergency travel documents to children for the first time (NAO 2015). The UKVI only assist nationals residing abroad in terms of partially processing some passport applications and renewals that, depending on host state, can be completed in-person at UKVI 'hub and spoke' centres ${ }^{1}$ that are located across the globe. However, in the majority of host states the application is processed online directly with Her Majesty's Passport Office (HMPO) - which is a further division of the Home Office - in the UK. Some minor functions may also fall to the Visa Application Centres located across the globe, but these mainly concern non-British nationals applying for a UK visa.

Whilst there is limited regional variation in the UK's policy towards Britons residing abroad, the Scottish Government adopted a diaspora engagement strategy in 2010 (Scottish Government 2010). The main mission of the diaspora engagement plan includes: Continue to build opportunities to engage with the Diaspora into planned Ministerial activities overseas, focusing on priority countries identified in the International Framework. The Scottish Government have conducted a number of consultations and research on the Scottish Diaspora. ${ }^{2}$ The Scottish Government already has a range of tools which successfully engage with an international audience and the Diaspora, including; (i) Scotland.org the official online gateway to Scotland; (ii) The Global Friends of Scotland and GlobalScot networks; (iii) and events such as Scotland Week in North America. The Scottish government's international framework on diaspora has three key objectives:

- Creating conditions for members of the Diaspora to live, learn, visit, work and return to Scotland

- Bring a sharp economic growth focus to the promotion of Scotland to the Diaspora

\footnotetext{
${ }^{1}$ https://assets.publishing.service.gov.uk/government/uploads/system/uploads/attachment_data/ file/361579/Myd ocument.pdf

${ }^{2}$ Including the following papers: The Scottish Diaspora and Diaspora Strategy: Insights and Lessons from Ireland; Engaging the Scottish Diaspora: Rationale, Benefits and Challenges; Scotland's Diaspora and Overseas-Born Population; and Scottish Government International Framework.
} 
- Managing Scotland's reputation with the Diaspora, as a distinctive global identity, an independent-minded and responsible nation, confident of its place in the world.

In contrast to the limited state engagement strategy with Britons residing abroad, the three main political parties have infrastructure to engage with citizens living abroad. The current administration - the Conservative Party (365 seats) - run the ConservativesAbroad ${ }^{3}$ branch established in the late 1990s, which provides a forum 'for like-minded people to socialise and gives a platform for political discussion on matters of mutual interest'. ConservativesAbroad were instrumental in in getting Votes for Life on the political agenda discussed below (Collard 2018). The aims of ConservativesAbroad are to keep Conservatives members and supporters living overseas in touch with politics at home; increasing the number of registered voters from abroad; increasing awareness of the issues facing British Citizens living overseas; and lobbying to reform overseas voting laws. The Labour Party (202 seats) similarly run Labour International, ${ }^{4}$ which has 2400 members in over 60 countries. The objective of Labour International - aside from promoting the values of the UK Labour Party and working with sister parties in different countries - are to provide a focal point for the social and political needs of Labour Party members and supporters living or working abroad, and developing electoral support for the Party among British subjects abroad. The smallest Party - the Liberal Democrats (11 seats) - established LibDems Abroad ${ }^{5}$ in 2010 which aims to help members and supporters stay in touch with the Party, ensure that the Party understands the concerns of its members overseas and to encourage members and supporters to register to vote in UK elections.

\subsubsection{Key Engagement Policies}

The UK is perhaps peculiar in contrast to other states in its lack of engagement policy or strategy with its citizens abroad. Current engagement by the British state with its diaspora population is limited by international standards (Finch et al. 2010, p. 9), and there is no governmental policy to speak of which actively engages with British citizens who have emigrated abroad (Hampshire 2013, p. 312). There is no state level representative or consultation mechanism or any dedicated institutional architecture for engaging with its overseas population, nor are there specific policies pertaining to remittances, return, education, housing or repatriation. State engagement is minimal and reactive to Britons residing overseas.

However, there are many initiatives led by the government that are of relevance to British emigrants and some targeted information campaigns. The FCO provide

\footnotetext{
${ }^{3}$ https://www.conservativesabroad.org/about-us

${ }^{4} \mathrm{http}: / / \mathrm{www}$. labourinternational.net/about

${ }^{5} \mathrm{https}: / /$ www.libdems.org.uk/abroad
} 
extensive advice on their websites and social media and is 'a world leader in providing online and other information in supporting emigrants to be well prepared for life overseas' (Finch et al. 2010, p. 11). This includes a 'Living Abroad Checklist', the Travel Aware website, retiring abroad, and tailored information for living and working (norms and rights) in every host state. Additionally, the government provide information on trading and investment advice for British nationals looking to emigrate including business factsheets, overseas Intellectual Property (IP) protection and guidance for setting up an overseas business.

The cornerstone of FCO policy is the (usually annually updated) booklet for Britons travelling overseas - Support for British Nationals Abroad: A Guide - that sets out the FCO customer charter and serves to outline how and when consulates can assist British nationals. The FCO also jointly ran an online video guide with the Buying Association to prepare Britons for buying property abroad. ${ }^{6}$ However, with the exception of the latter, most of these initiatives are orientated towards all British national travelling, not necessarily or specifically Britons residing abroad.

The UK state has limited diaspora integration in the way of 'extending political rights' (Gamlen 2008) Dual citizenship and external voting (by post or proxy) is permitted although voter registration is 'pitifully small' (Finch et al. 2010, p. 70). The Electoral Commission run a specific online page for online voters to enquire and register. ${ }^{7}$ Voting rights of national residing abroad has been an especially contentious issue in British politics following the EU referendum in 2016. The current system of electoral registration for national elections (and referendums depending on the franchise) allows Britons residing abroad to continue to vote for 15 years in the constituency where they were last registered. This meant that many British citizens residing abroad were ineligible to vote in the 2016 referendum despite British emigrants residing in the EU being highly affected by the vote, roughly estimated as up to two thirds of the population disenfranchised as a result of the 15-year residency rule (Benson 2019).

IPPR's (2010) qualitative research commissioned by the FCO found that the overall low levels of voter registration is due to 'the laborious processes of vote registration and casting postal or proxy votes' which 'appears to deter all but the most committed individuals' (Finch et al. 2010, p. 70). Collard (2018) similarly surmises that registration levels for overseas voters were low 'largely due to bureaucratic obstacles'. A study conducted by the Electoral Commission (2016) highlighted a number of barriers to casting a ballot overseas, including confusion over eligibility requirements (with some $31 \%$ of respondents believing that receiving a UK state pension or owning property in the UK made them eligible to vote), low levels of understanding that an overseas voter registration has to be renewed annually, along with a lack of awareness of how to register or vote (Electoral Commission 2016). The Association of Electoral Administrators (AEA 2017, p. 51) found that in the 2017 General Election, there were many incidences where overseas voters

\footnotetext{
${ }^{6} \mathrm{https} / / /$ www.buyassociation.co.uk/fco-overseas-property-buying-guide/

${ }^{7}$ https://www.yourvotematters.co.uk/can-i-vote/overseas
} 
mistakenly believed that they would be able to vote online or have their ballot papers emailed to them.

Registered overseas voters have nonetheless increased to over 285,000 largely due to the introduction of online registration in the 2014 and 2016 referendums and the 2015 and 2017 general elections (Collard 2018; Johnston 2018, p. 16). A further 132,048 British citizens abroad registered to vote between October and November 2019 ahead of the December 2019 General Election (Benson 2019). However, in the Second Reading debate on the Overseas Electors Bill 2017-2019, Cabinet Office Minister said 'that the number of registered overseas voters at the June 2017 General Election, just over 285,000 , represented about only 20 per cent of the number likely to be eligible', giving a potential electorate of around 1.4 million (Johnston 2018, p. 15). In a research survey conducted by the Electoral Commission of UK citizens living overseas $58 \%$ of respondents believed that they were currently registered and $30 \%$ of potentially eligible overseas voters responded that they had voted in the 2015 UK General Election (Electoral Commission 2016, p. 3). Having said this, these figures should be treated cautiously.

Since the referendum a number of grassroot networks of UK citizens resident in the EU have sprung up to lobby government for secure residency status following Brexit. The Conservative Party pledged in their 2014 manifesto to grant 'Votes for Life' to UK citizens resident abroad, which will mean abolishing the current rule which disenfranchises UK citizens who have been resident abroad for more than 15 years. In October 2016 the Conservative government published a policy statement on 'A democracy that works for everyone: British citizens overseas', which set out how the 15 year rule will be removed. The Overseas Electors Bill 2017-2019 was a private members bill that sought to end the 15-year time limit that took place in February 2018. The Bill 'to make provision extending the basis on which British citizens outside the UK qualify to participate in parliamentary elections; and for connected purposes' completed its public committee stage in November 2018 (House of Commons 2018). However, the Bill was filibustered by Conservative MP Phillip Davies - a member of the European Research Group and an ardent Brexiter at the report stage (Collard 2019). Thus the Bill was killed off.

Whilst there are a number of privately led networks for British nationals residing abroad, such as Expat Network, ${ }^{8}$ there is no specific state sponsored consultative or representative body or mechanism for UK nationals residing abroad. The FCO's main channel of communication and responding to queries from Britons living abroad (aside from physical consulates and embassies) is through social media, where the FCO have dedicated Facebook and twitter pages for British emigrants. The FCO have made concerted efforts in recent years to publish up-to-date and bespoke travel advice for Britons and utilising social media as the key platform for communications. The latter has included terminating the LOCATE database - to register British emigrants - in 2013 when the FCO claimed that social media has superseded LOCATE system for registering details with an Embassy, especially in

\footnotetext{
${ }^{8} \mathrm{https}: / /$ www.expatnetwork.com
} 
light of the fact that only $1 \%$ of British emigrants used the registry service (British Embassy Cairo 2013). Most embassies have a dedicated Facebook site for each host state specifically for Britons residing abroad where citizens are encouraged to engage with each other.

British embassies and high commissions regularly hold conferences and events around the world - many of which are targeted at British emigrants - where the FCO can provide Q\&A sessions on specific issues for Britons. Consulate efforts to hold discussions for Britons residing in Europe have seemingly increased since the referendum due to the uncertainty of status for Britons living in the EU. For example, in April 2018 the British Embassy in Paris held meetings across France to hear concerns around Brexit and residency status from Britons living in France locations (British Embassy Paris 2018). Likewise, the British Embassy in Spain held meetings in 2016 at local town halls to allow Britons residing in Spain to feedback their concerns around Brexit (British Embassy Consulate Palma de Mallorca 2016). Consulates can also provide details on any local clubs or organisations for British expatriate communities (FCO 2018). Furthermore, embassies and consulates often have close contacts with British businesses - with two overseas missions sharing premises with business groups (Hampshire 2013, p. 314) - such as through British Business Forums ${ }^{9}$ (in Macedonia for example) and some embassies and/or high commissions specifically state that their mission is to support British businesses operating in host states.

\subsection{Diaspora Policies and Social Protection in the United Kingdom}

The UK government has a complete absence of policies to facilitate the access to social protection of national residing abroad. This absence stems from the fact that British emigrants tend to be high skilled, prosperous, moving for high skilled work, and lifestyle migration. British emigration has long been driven by positive pull factors underpinned by voluntarism then, rather than negative push factors that might lead to deprivation in the sending state. Combined with assumptions that Britons living abroad do not want or need to engage with the homeland state, there has been little incentive for the government to establish social protection policies.

Britons residing abroad cannot claim any UK means-tested or income-based benefits, and therefore there are no guaranteed minimum income benefits available for Britons residing abroad from the UK government. Policy is geared towards informing Britons of their social protection rights both from the home and host state via the FCO and gov.uk websites. Policy, not legal right, underpins consular affairs and therefore the state is under no legal obligation to provide consular assistance. The FCO is not funded to provide emergency assistance or any kind of in-cash

\footnotetext{
${ }^{9}$ https://www.gov.uk/world/macedonia/news
} 
benefits or any economic assistance in any capacity. If all other options have been exhausted and only in exceptional circumstances the FCO can provide an emergency loan to help a Briton (tourist or emigrant) return to the UK on a discretionary basis $^{10}$ (FCO 2018). In such cases, if the Briton is eligible they must sign a 'undertaking to repay' agreement with the FCO and secure their loan by giving up their passport to the FCO. However, this is discretionary and rarely deployed. Whilst the FCO is responsible for coordinating matters with other UK government departments, there is no policy or evidence of consulates assisting Britons living abroad with social protection claims or welfare entitlements, although, as assistance is discretionary, this may transpire in practice. The Department for Work and Pensions (DWP) are responsible welfare, pensions and child maintenance policy.

\subsubsection{Unemployment}

There is no specific policy pertaining to assisting Britons residing abroad access to unemployment benefits and the consulate services have no outlined role in facilitating or assisting Britons in claiming any welfare entitlements. However, the UK government provide extensive advice on eligibility for home unemployment benefits via their website, and allow Britons to find out which UK benefits they can retrieve and host state benefits via an online questionnaire. ${ }^{11}$

The main unemployment benefit in the UK is Jobs Seekers Allowance (JSA), of which there are two types: contribution based and income based. Britons residing abroad are not eligible to claim any income-based or means tested unemployment benefits, which refers to income based JSA. Due to EU legislation, Britons residing abroad can claim contribution-based JSA in the EEA or Switzerland states for up to 3 months after leaving the UK, subject to other eligibility criteria, including:

- Being entitled to JSA on the day of departure

- Registering as a jobseeker at least 4 weeks before departure

- Looking for work in the UK up until the day of departure

- Emigrating abroad to look for work

- Registering at the equivalent of a Job Centre in the host state

- Following the state country's rules on registering and looking for work.

Britons cannot usually claim contribution based JSA in non-EEA states. Some countries outside the EEA have social security agreements with the UK. This means that if a Briton has paid enough National Insurance contributions in the UK, they may be able to get unemployment benefits in: Bosnia and Herzegovina, Channel

\footnotetext{
${ }^{10}$ There are exceptional cases where the UK government - not necessarily the FCO - has repatriated Britons. For example, in October 2017 the government (Department of Transport) ordered the country's largest peacetime repatriation to fly 110,000 Britons back to the UK following the collapse of airline Monarch.

${ }^{11} \mathrm{https}: / /$ www.gov.uk/uk-benefits-abroad
} 
Islands, Kosovo, Macedonia, Montenegro, New Zealand and Serbia. The UK government can assist with benefit claims from EU host states in a limited way by providing a form U1 which is a record of UK National Insurance contributions that may help a claim for unemployment benefit in another EU country. The government provide a list of countries online where Britons can potentially claim unemployment benefits in the host state. However, the website states that benefit arrangements will depend on the specific host state.

The website advices that an applicant contact their local Job Centre before departure to ensure there are no forms to fill out. The government provide an international line for enquiries on claiming Jobs Seekers Allowance from abroad via the International Pension Centre, which provide separate international phone numbers for differing unemployment benefits including pro-rata Employment and Support Allowance (ESA) and Jobs Seekers Allowance (JSA). Further advice on claiming benefits in host non-EEA states are on ndirect.gov.uk.

\subsubsection{Health Care}

There is no specific policy to assist Britons living abroad with healthcare. Much like unemployment benefits the government provides extensive advice on accessing home and health country provision via the FCO and gov.uk websites. The National Health Service (NHS) is the public health services in the UK. Each of the UK's health service systems operates independently, and is politically accountable to the relevant government: the Scottish Government, Welsh Government, Northern Ireland Executive and the UK government, responsible for England's NHS. NHS England is an executive non-departmental public body, sponsored by the Department of Health and Social Care. Whilst there is usually no regional difference in UK policies towards its citizen's abroad, access to healthcare in Scotland is a marked exception. According to NHS Scotland if a UK passport holder works anywhere outside the UK they can get healthcare from the NHS in Scotland if they lived in the UK legally for more than 10 years before moving abroad in addition to the following requirements: if they have come back to the UK for a visit at least once every 2 years, their contract of employment allows them to visit the UK at least once every 2 years, and their employer will pay for the cost of their return to the UK at the end of their contract. ${ }^{12} \mathrm{~A}$ further exception worth highlighting is the agreement between the UK and Ireland specifically. The UK and Irish authorities have an agreement where UK residents do not need their European Health Insurance Card (EHIC) to access healthcare services if they are on a temporary stay in Ireland. It is enough to show proof that you are ordinarily resident in the UK, such as a driving licence, passport or similar documentation that shows your NHS number or its equivalent.

\footnotetext{
${ }^{12} \mathrm{https}$ ///www.nhsinform.scot/care-support-and-rights/health-rights/access/ healthcare-for-uk-passport-holders-living-or-working-abroad
} 
The NHS provide information online for Britons moving abroad which details all relevant information regarding health and provides a country-by-country guide for the specific healthcare infrastructure in host states. Further advice on covering medical costs when moving abroad are available on the NHS website. ${ }^{13}$ A more general overview of health factors abroad can be found in the FCO guide Support for British Nationals Abroad (FCO 2018). The FCO advises that all Britons, whether travelling ore moving abroad, seek out private health insurance.

The NHS is a residence-based healthcare system and therefore Britons moving permanently abroad are not automatically entitled to medical treatment. The UK NHS does not cover British nationals if they are going to be living permanently outside the EEA. If a Briton has lived outside the UK for more than 3 months (6 months for pensioners living in EEA countries) than they may be liable for charges using NHS services when returning to Britain, although they are eligible for free medical treatment in Accident and Emergency departments of NHS hospitals. However, a Briton is exempt from charges if they can: produce evidence that they have been working abroad in a EEA country or a country with which the UK has a bilateral healthcare agreement for less than 5 years and have lived in the UK continuously for at least 10 years at some point, or provide evidence that they work in another EEA country or Switzerland and pay compulsory (not voluntary) national insurance in the UK.

The UK has a number of bilateral healthcare agreements with non-EEA countries. However, these agreements are based on a Briton being a lawful UK residence and therefore reciprocal agreements namely cover visits/tourists as opposed to Britons living abroad. If a Briton has lived in the UK for 10 continuous years at some point but are now living in an EEA member state or another state with which the UK has a bilateral healthcare agreement with, then under UK law they are entitled to free of charge treatment (not including planned treatment).

Under the FCO customer charter, the FCO stipulates that they may help Britons to access medical treatment or medication if they are suffering serious medical problems because of serious disruptions. The FCO Customer Charter stipulates that the FCO can provide Britons with a list of local doctors, medical facilities and hospitals in every host state. However, the FCO cannot pay for medical treatment for Britons living abroad and there is no policy to provide cash benefits to deal with health issues. The FCO have a policy of Exceptional Assistance Measures (EAM) which provide additional practical support to British nationals who are the victim of terrorist overseas; these measures may go beyond the usual help the FCO aim to provide and can include medical evacuation, payment of immediate medical expenses and repatriation. The FCO stipulate unequivocally that they do not provide funds for repatriation including medical repatriation outside of exceptional EAM measures (see above for exception for repatriation).

\footnotetext{
${ }^{13}$ https://www.nhs.uk/NHSEngland/Healthcareabroad/movingabroad/Pages/Introduction.aspx
} 


\subsubsection{Pensions}

Britons retiring abroad can claim their UK state pension if they have paid enough UK national insurance contributions to qualify. Britons living abroad cannot access means-tested welfare and are therefore not eligible for pension credit. British pensioners living overseas can claim their UK state pension by either contacting the International Pension Centre (IPC) or sending an international claim form directly to the IPC. The International Pension Centre provides full advice and advisors are on hand to issue advice on pension claims. The government provide detailed information on how to claim UK state pension from abroad online. Furthermore, the Pensionary Advisory Service (TPAS) is an independent organisation grant-aided by the DWP that supplies free, impartial advice on UK pensions including for Britons residing abroad. Her Majesty's Revenue and Custom (HMRC) - a non-ministerial department of the UK Government responsible for the collection of taxes, the payment of some forms of state support and the administration of other regulatory regimes including the national minimum wage - allows pensioners to transfer their UK state pension to an overseas pensions scheme if such scheme is on the recognised overseas pension scheme notification list (lists for each host state pension scheme are available online).

Claimants may be asked to fill out a 'life certificate' to ensure they are eligible for UK state pension. Since 2013 the DWP has operated a proof of life programme (referred to as a Life Certificate) where state pensioners residing permanently outside of the UK are required to provide independent evidence in the form of a witness statement, confirming that the applicant is alive. The DWP sends the life certificate form to an applicant after they have registered with the IPC. The consulate plays no role in the processing of life certificates. To avoid having their pension frozen, claimants have 9 months to fill out and send their life certificate forms. Life certificates are not mandatory; however, in any change in circumstance (such as address change) claimants will need to fill and register a life certificate. There is no specific policy or exemptions in FCO policy for pensioners for repatriation.

The FCO advise pensioners retiring abroad to seek a State Pension Forecast from the DWP before emigrating. Pensioners must be within 4 months of state pension age to claim their pension. State pensions only increase annually if the pension applicant lives in the EEA, Switzerland, Gibraltar or countries that have a social security agreement with the $\mathrm{UK}^{14}$ (although no increases if a Briton is living in New Zealand or Canada).

Inflation adjustment on UK pension contributions has been a contentious issue amongst both British nationals and host states in terms of reciprocal social security agreements for a number of years. For example, in 2001 Australia terminated the Social Security Agreement with the UK 'because the UK Government refuses to change its policy of not indexing pensions in Australia, even though it does index

\footnotetext{
${ }^{14}$ Barbados, Bermuda, Bosnia-Herzegovina, Jersey, Guernsey, the Isle of Man, Israel, Jamaica, Kosovo, Macedonia, Mauritius, Montenegro, the Philippines, Serbia, Turkey and USA.
} 
pensions paid in some countries with which it has Agreements' therefore there will be no early access to Australia's social security system for migrants from the UK. ${ }^{15}$ The UK State Pension is payable overseas only uprated annually if the individual is resident in an EEA country or one with which the UK has a reciprocal social security agreement requiring this. UK pensioners in other countries - most notably Australia, Canada, New Zealand and South Africa - have their pension frozen i.e. paid at the same rate as it was when they first became entitled, or the date they left the UK if they were already pensioners then.

The policy of not awarding increases in some countries overseas has been followed by successive governments and continued with the introduction of the new State Pension in April 2016. Essentially, 'the reason is cost and the desire to focus constrained resources on pensioners in the UK' (Thurley and McInnes 2018, p. 3). In 2018 Pensions Minister, Guy Opperman, set out the reasons for the policy on uprating pensions:

There are two main reasons for not paying annual up-ratings to non-residents. First, upratings are based on levels of earnings growth and price inflation in the UK which have no direct relevance where the pensioner is resident overseas. Second, the cost of up-rating state pensions overseas in countries where we do not currently up-rate would increase immediately by over $£ 0.5$ billion per year if all pensions in payment were increased to current UK levels (PQ 131353, 12 March 2018 cited from Thurley and McInnes 2018, p. 3).

The All Party Parliamentary Group (APPG) on Frozen British Pensions has lobbied the case for "partial uprating" - which means currently frozen pensions would be uprated going forward, from their current rate. It estimated the "upfront cost" of this at $£ 37$ million (Ibid). The arrangements to apply in EU countries in future have been a major subject of the negotiations on Brexit. A joint technical note on the comparison of EU-UK positions on citizen's rights published on 28 September 2017 said both sides had committed to lifetime export of uprated pension (Thurley and McInnes 2018, p. 3).

\subsubsection{Family-Related Benefits}

Britons living abroad can get Child Benefit for children living with them within the EEA or Switzerland. The applicant must pay National Insurance in the UK - and therefore they are or were employed or self-employed - or get 1 of the following benefits: Contribution-based Jobseeker's Allowance, Incapacity Benefit, Contribution-based Employment and Support Allowance, State Pension, Bereavement Allowance (Widow's Pension), Industrial Injuries Disablement Benefit. If the applicant and their partner live in different countries, then the applicant may qualify for Child Benefit or its equivalent in both host states. The country

\footnotetext{
${ }^{15} \mathrm{https} / / / \mathrm{www} . d \mathrm{dss} . g o v . a u /$ about-the-department/international/international-social-security-agreements/terminati on-of-the-social-security-agreement-with-the-united-kingdom-uk-1-march-2001/ termination-of-the-social-security-agreement-with-the-uk-information-for-prospective-migrants
} 
the child lives in will usually pay the benefit. If the benefit is more in the other country, that country will pay the applicant extra. Britons living abroad cannot claim means-tested or income-based benefits and therefore do not qualify for the Sure Start Maternity Grant - a one off payment of $£ 500$ for a first child.

Britons living overseas may be able to get child benefits in countries with which the UK has a social security agreement. Applicants are instructed to contact the Child Benefits Office (within HMRC) to find out if they can make a claim. The government provides extensive information on eligibility for child benefits for Britons living abroad, and the Childs Benefits Office, whilst not exclusively focused on Britons living overseas, provides advice on claiming child benefits including a dedicated phone number for overseas calls and a live webchat. As outlined, consular assistance is based on policy, not legal right. There is no policy to assist Britons in claiming UK or host family benefits, however consular assistance is discretionary and on a case-by-case basis depending on vulnerability.

\subsubsection{Economic Hardship}

There is no UK policy on ensuring that Britons residing abroad have guaranteed minimum resources, including in cases of homelessness. Britons residing abroad cannot claim any UK means-tested or income-based benefits, and therefore there are no guaranteed minimum income benefits available for Britons residing abroad from the UK government. Whilst some UK welfare entitlements can be accessed outside of the UK, other welfare entitlements are only applicable in host states where the UK has a reciprocal agreement. UK nationals can claim some contributions based state benefits (the majority are outlined above) - eligibility is varied, often dependent on residency, and only in countries where social security agreements exist.

The FCO advice for Britons residing abroad is to contact the social security branch of the HMRC national insurance contributions (international services), as well as the DWP. Whilst consular assistance is not a legal right and there is no policy to assist Britons residing abroad access to guaranteed minimum resources, as consular assistance is discretionary and based on vulnerability, in practice consulates may assist Britons in accessing information or coordinating with the DWP. For example, the Spanish Embassy advices online to seek out what income-related benefits are available in Spain by speaking to a social worker (trabajador social) at the Britons' local town hall or to visit the nearest Instituto de Mayores y Servicios Sociales Office. Some embassies in host states can provide Britons in need with a list of legal aid organisations to help assist in their claims of economic hardship. As set out in the FCO customer charter, consulates will provide details of other organisations in the host state that can provide specialist support where the FCO are unable.

The government provide information specifically for Britons residing abroad to claim UK welfare entitlements on their website. Aside from general guidance online 
from the DWP, there are no other specific services offered to Britons residing abroad for guaranteed minimum resources.

\subsection{Conclusions}

In this chapter I have shown that the UK policies for its citizens abroad are characterised by providing comprehensive information whilst remaining passive in its engagement. The British state remains disengaged with its diaspora, whilst keeping the dialogue open through impressive information campaigns and social media channels. British emigrants tend to be prosperous and migrate for lifestyle underpinned by voluntarism motivations and therefore there has been little incentive to establish social protection policies or indeed engage with its diaspora.

The UK lacks any diaspora engagement policy or social protection policies for its nationals residing abroad, and is therefore underpinned by a passive approach to its emigrants. By international standards the UK remain limited in its engagement strategy which is curious given that the UK has one of the largest and most widely dispersed overseas population of any country (Hampshire 2013 p. 303). The British diaspora make a large potential voting pool and is composed of high skilled, high income individuals who could be potential ambassadors and soft power for Britain across the globe (Finch et al. 2010; Hampshire 2013, p. 319). Drawing on the limited literature on the UK diaspora, scholars argue that the absence of engagement is due to: the lack of distinctive British national identity, the heterogeneity of the British diaspora meaning that forming a cohesive policy that responds to its emigrants is challenging, but perhaps most importantly the British diasporas' 'apparent indifference to being engaged by the government... and they do not make much use of such channels as to impel politicians to represent their interests' (Hampshire 2013, p. 319-21).

Government's efforts to engage with its diaspora are solely through online information campaigns and social media as part of the FCO digital first strategy (Foreign Affairs Committee 2014). This being said, the FCO have made headways in recent years in ensuring online information for Britons travelling or moving abroad is upto-date, that social media is engaging and responsive, and that government websites detailing advice for Britons moving abroad are extensive and comprehensive. Consulates are responsive to the needs of British nationals if and when needed and the Foreign Affairs Committee concluded on consular services in 2014 that

The Consular Service has responded with a "strategic shift" to provide a more standardised and professional service, with greater clarity on what it can and cannot provide, and a new focus on the most vulnerable. This has resulted in some welcome innovations, such as global call centres to remove the pressure from consular officers (Foreign Affairs Committee 2014 p. 3).

Conversely, the politics of British emigrants is relatively high on the political agenda, in the sense that ongoing Brexit negotiations are likely to have a significant 
impact on Britons residing in the EU, and their entitlement and access to social protection in EU host states. Many Britons resident in the EU are aggrieved at the both the result of the referendum, and the 15-year time limit voting rule that prevented many Britons from being able to vote on an issue that affects them so significantly. With the VFL Bill killed at the report stage in 2019, the 15-year residency rule looks set to remain. Divisive Brexit politics means it is likely that the 15 -year rule will continue to be contentious, and that the government through its consulate services will need to be more consistently engaged with Britons concerned over their residency status and social protection rights in the EU. Whilst pension increases for Britons residing in the EU has been confirmed and is unlikely to be a sticking point in negotiations, the outcome of agreements are bound to affect social protection rights for Britons in the EU.

Acknowledgements This chapter is part of the project "Migration and Transnational Social Protection in (Post)Crisis Europe (MiTSoPro)" that has received funding from the European Research Council (ERC) under the European Union's Horizon 2020 research and innovation programme (Grant agreement No. 680014). In addition to this chapter, readers can find a series of indicators comparing national social protection and diaspora policies across 40 countries on the following website: http://labos.ulg.ac.be/socialprotection/.

\section{References}

Association of Electoral Administrators [AEA]. (2017). AEA post-elections report 2017: It's time for urgent and positive Government action. https://www.aea-elections.co.uk/wp-content/ uploads/2017/09/aea-post-election-report-mayjune-2017.pdf. Accessed 4 Jan 2019.

Benson, M. (2019). The election and the overseas vote in the EU. UK in a Changing Europe. https://ukandeu.ac.uk/the-election-and-the-overseas-vote-in-the-eu/

British Consulate Palma de Mallorca. (2016). British Deputy Head of Mission in Spain listens to British residents' concerns following EU referendum. https://www.gov.uk/government/news/ british-deputy-head-of-mission-in-spain-listens-to-british-residents-concerns-following-eureferendum. Accessed on 8 Mar 2018.

British Embassy Cairo. (2013). LOCATE switch-off. https://www.gov.uk/government/news/locateswitch-off\%2D\%2D2. Accessed 10 Mar 2018.

British Embassy Paris. (2018). British Embassy Paris meeting British Citizens across France. https://www.gov.uk/government/news/british-embassy-paris-meeting-british-citizens-acrossfrance. Accessed 10 Mar 2018.

Bueltmann, T., Gleeson, D. T., \& MacRaild, D. (2012). Locating the English diaspora: Problems, perspectives and approaches. In T. Bueltmann, D. T. Gleeson, \& D. MacRaild (Eds.), Locating the English diaspora, 1500-2010 (pp. 1-15). Liverpool: Liverpool University Press.

Cohen, R. (2008). Global diasporas: An introduction. Oxon: Routledge.

Collard, S. (2018). Overseas Electors Bill: Does government really intend to give expats 'votes for life'? LSE Blog British Politics \& Policy. http://blogs.lse.ac.uk/politicsandpolicy/votes-forlife/. Accessed 10 Mar 2018.

Collard, S. (2019). He killed the bill: Britosn living abroad for more than 15 years still don't have a vote. LSE Blog. https://blogs.lse.ac.uk/brexit/2019/04/09/ he-killed-the-bill-britons-living-abroad-for-more-than-15-years-still-dont-have-a-vote/

Dennison, J., \& Geddes, A. (2018). Brexit and the perils of 'Europeanised' migration. Journal of European Public Policy, 25(8), 1137-1153. 
Electoral Commission. (2016). Survey of UK citizens living overseas Summary of findings. https:// www.electoralcommission.org.uk/_data/assets/pdf_file/0004/215788/Electoral-CommissionSurvey-of-UK-citizens-living-overseas-summary-of-findings-Sep-2016.pdf. Accessed 15 Mar 2018.

Finch, T., Andrew, H., \& Latorre, M. (2010). Global brit: Making the most of the British diaspora. London: IPPR. https://www.ippr.org/files/publications/pdf/global-brit_2010.pdf. Accessed 15 Mar 2018.

Foreign Affairs Committee. (2014). Fifth report support for British nationals abroad: The Consular Service. https://publications.parliament.uk/pa/cm201415/cmselect/cmfaff/516/51602.htm. Accessed 5 Mar 2018.

Foreign and Commonwealth Office [FCO]. (2018). Support for British nationals abroad: A guide. London: HM Government. https://www.gov.uk/government/publications/support-for-britishnationals-abroad-a-guide. Accessed 15 Mar 2018.

Gamlen, A. (2008). The emigration state and the modern geopolitical imagination. Political Geography, 27(8), 840-856.

Hall, I. (2013). Building the global network? The reform of the Foreign and Commonwealth Office under New Labour. The British Journal of Politics and International Relations, 15(2), 228-245.

Hammerton, A. J. (2017). Migrants of the British diaspora since the 1960S: Stories from modern nomads. Manchester: Manchester University Press.

Hampshire, J. (2013). An emigrant nation without an emigrant policy: The curious case of Britain. In M. Collyer (Ed.), Emigrant nations: Policies and ideologies of emigrant engagement (pp. 302-327). New York: Palgrave Macmillan.

House of Commons. (2018). Overseas Electors Bill, first sitting 17 October 2018, PBC (Bill 016)2017-2019. London: House of Commons. https://publications.parliament.uk/pa/ cm201719/cmpublic/OverseasElectors/PBC016_Overseas\%20Electors\%20Bill_1st-4th_ Combined_14_11_2018.pdf. Accessed 10 Jan 2019.

Howard, R. W. (2008). Western retirees in Thailand: Motives, experiences, wellbeing, assimilation and future needs. Ageing \& Society, 28, 145-163.

Inter Nations. (2017). Expat Insider 2017: Fleeing the British weather forever. https://www.internations.org/expat-insider/2017/the-british-abroad-39186. Accessed 15 Feb 2019.

Johnston, N. (2018). Overseas voters. London: House of Commons Briefing Paper, Number 5923, 1 March 2018. researchbriefings.files.parliament.uk/documents/SN05923/SN05923.pdf. Accessed 10 Jan 2019.

King, R., \& Patterson, G. (1998). Diverse paths: The elderly British in Tuscany. International Journal of Population Geography, 4, 157-182.

King, R., Warnes, T., \& Williams, A. (2000). Sunset lives: British retirement migration to the Mediterranean. Oxford: Berg.

Murray, R., Harding, D., Angus, T., Gillespie, R., \& Arora, H. (2012). Emigration from the UK: Research Report 68. London: Home Office. https://assets.publishing.service.gov.uk/government/uploads/system/uploads/attachment_data/file/116025/horr68-report.pdf. Accessed 15 Feb 2019.

National Audit Office [NAO]. (2015). A Short Guide to the Foreign \& Commonwealth Office. London: NAO. https://www.nao.org.uk/wp-content/uploads/2015/08/Foreign-CommonwealthOffice-short-guide1.pdf. Accessed 10 Feb 2019.

O'Reilly, K. (2000). The British on the Costa Del Sol. London: Routledge.

Office for National Statistics [ONS]. (2018). Living abroad: British residents living in the EU: April 2018. https://www.ons.gov.uk/peoplepopulationandcommunity/populationandmigration/ internationalmigration/articles/livingabroad/april2018. Accessed 15 Feb 2019.

Ragazzi, F. (2014). A comparative analysis of diaspora policies. Political Geography, 41, 74-89.

Scottish Government. (2010). Diaspora Engagement Plan - Reaching out to Scotland's International Family. Edinburgh: Scottish Government.

Sriskandarajah, D., \& Drew, C. (2006). Brits abroad: Mapping the scale and nature of British emigration. London: IPPR. 
Thurley, D., \& McInnes, R. (2018). Frozen overseas pensions. London: House of Commons. Warnes, A. M., King, R., Williams, A. M., \& Patterson, G. (1999). The well-being of British expatriate retirees in southern Europe. Ageing and Society, 19, 717-740.

World Bank. (2011). Migration and remittances factbook 2011. Washington, DC: The World Bank.

Open Access This chapter is licensed under the terms of the Creative Commons Attribution 4.0 International License (http://creativecommons.org/licenses/by/4.0/), which permits use, sharing, adaptation, distribution and reproduction in any medium or format, as long as you give appropriate credit to the original author(s) and the source, provide a link to the Creative Commons license and indicate if changes were made.

The images or other third party material in this chapter are included in the chapter's Creative Commons license, unless indicated otherwise in a credit line to the material. If material is not included in the chapter's Creative Commons license and your intended use is not permitted by statutory regulation or exceeds the permitted use, you will need to obtain permission directly from the copyright holder.

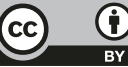

